\title{
Impact of maternal nutrition during pregnancy on pituitary gonadotrophin gene expression and ovarian development in growth-restricted and normally grown late gestation sheep fetuses
}

\author{
P. Da Silva' ${ }^{1}$, R. P. Aitken ${ }^{1}$, S. M. Rhind ${ }^{2}$, P. A. Racey ${ }^{3}$ \\ and J. M. Wallace ${ }^{1 *}$ \\ ${ }^{1}$ Rowett Research Institute, Bucksburn, Aberdeen AB21 9SB, UK; ${ }^{2}$ Macaulay Land Use \\ Research Institute, Craigiebuckler, Aberdeen AB15 8QH, UK; and ${ }^{3}$ Department of Zoology, \\ University of Aberdeen, Aberdeen AB24 2TZ, UK
}

The influence of maternal nutrition during pregnancy on anterior pituitary gonadotrophin gene expression and ovarian development in sheep fetuses during late gestation was investigated. Embryos recovered from superovulated adult ewes that had been inseminated by a single sire were transferred, singly, into the uteri of adolescent recipients. After embryo transfer, adolescent ewes were offered a high or moderate amount of a complete diet. Pregnancies were terminated at day $131 \pm 0.6$ of gestation and the fetal brain, anterior pituitary gland and gonads were collected. Gonadotrophin gene expression (LH $\beta$ and FSH $\beta$ subunits) in the fetal pituitary gland was examined using in situ hybridization. Ovarian follicular development was quantified in haematoxylin- and eosin-stained ovarian sections embedded in paraffin wax. Six dams that were offered a high nutrient intake carried normal-sized fetuses (weight within \pm 2 SD of mean weight for control fetuses from dams fed a moderate level of complete diet) and 13 dams carried growth-restricted fetuses (weight $\leqslant \pm 2$ SD of mean weight for control fetuses from dams fed a moderate level of complete diet). Mean placental masses in these groups were $354 \pm 24.5$ and $230 \pm 21.1 \mathrm{~g}$, respectively, compared with $442 \pm 54.3 \mathrm{~g}$ in the dams that were offered a moderate nutrient intake $(n=6)$. Growthrestricted fetuses from dams offered a high nutrient intake showed higher pituitary LH $\beta$ mRNA expression $(P<0.05)$ than normal-sized fetuses from dams offered a moderate nutrient intake $\left(252 \pm 21.6\right.$ and $172 \pm 23.6 \mathrm{nCi} \mathrm{g}^{-1}$, respectively). FSH $\beta$ mRNA expression was not influenced by growth status. Fewer follicles (primarily in the resting pool) were observed in the ovaries of both growthrestricted $(P<0.002)$ and normal-sized fetuses from dams offered a high nutrient intake $(P<0.01)$ compared with normal-sized fetuses from dams offered a moderate nutrient intake. Irrespective of nutritional treatment, the total number of follicles was positively associated with placental mass $(P<0.01)$. Thus, a high maternal nutrient intake during adolescent pregnancy had a negative influence on ovarian follicular development in fetuses as determined during late gestation.

\section{Introduction}

Successful reproduction in adult life depends on appropriate development of the reproductive axis, and much of the structural and neuroendocrine development of the components of the hypothalamic-pituitary-gonadal axis occurs during prenatal life (Brooks et al., 1992; Caldani et al., 1995; McNatty et al., 1995). In normally growing sheep fetuses, LH and FSH gonadotrophs are present in the anterior pituitary gland by day 70 and day 100 of gestation, respectively (Thomas et al., 1993) and the fetal gonadotrophin response to exogenous GnRH is highest after day 100 of gestation (term $=145$ days; Mueller et al., 1981). Thereafter, gonadotrophin concentrations decrease in response to evolving feedback mechanisms from sex

${ }^{*}$ Correspondence

Email: Jacqueline.Wallace@rri.sari.ac.uk steroids of both placental and gonadal origin (Gluckman et al., 1983; Mesiano et al., 1991) in association with increased central nervous system inhibition of $\mathrm{GnRH}$ (Brooks et al., 1995). In the fetal ovary, the maximum number of germ cells is present at day 75 of gestation (McNatty et al., 1995). At this stage, the first primordial follicles have formed and a large proportion of the germ cells is lost or degenerates beyond this point ( $80 \%$ between day 75 and day 90 when follicles are forming). Primary and secondary follicles are present in the ovarian cortex of sheep by day 100 and day 120 of gestation, respectively (McNatty et al., 1995, 2000).

It is postulated that environmental factors, such as maternal nutrition, which is known to influence the prenatal growth trajectory and physiology of the major organ systems (Robinson et al., 1999), may also have an adverse effect on the prenatal development of the components of the reproductive axis. Studies on animals and humans 
indicate that impaired prenatal growth can subsequently influence various aspects of postnatal reproductive development, including age at puberty (Ibãnez et al., 2000a,b; Da Silva et al., 2001), age at menopause (Cresswell et al., 1997) and the incidence of male subfertility (Francois et al., 1997). However, little is known about the effect of maternal nutrient intake on the development of the reproductive axis prenatally. A comparison of twin-bearing ewes that received either a low $(0.5 \times$ maintenance energy requirements $)$ or high $(1.5 \times$ maintenance energy requirements) intake during the first third of pregnancy revealed that germ cell degeneration was retarded in the low nutrient intake group at both day 47 and day 62 of gestation (Borwick et al., 1997). These early effects appeared to be independent of changes in placental mass or fetal weight.

In contrast, overnourishing the rapidly growing adolescent sheep throughout pregnancy resulted in a profound reduction in placental growth, which led to a significant decrease in birth weight compared with moderately fed adolescent ewes (Wallace et al., 1996). This paradoxical situation arises because high maternal nutrient intake promotes a major anabolic drive to maternal tissue synthesis at the expense of the evolving nutrient requirements of the gravid uterus (Wallace et al., 1997). The aim of the present study, using this model, was to determine whether this form of nutritionally mediated placental and fetal growth restriction influences anterior pituitary gonadotrophin gene expression and ovarian development of (approximately day 131) female fetuses in late gestation. By this stage of gestation, the normally growing fetus is considered to have achieved $80-85 \%$ of its final birth weight (Robinson, 1977) and the components of the hypothalamic-pituitary-ovarian axis are considered fully functional.

\section{Materials and Methods}

\section{Animals and experimental design}

All procedures were licensed under the UK Animals (Scientific Procedures) Act of 1986. Embryos recovered on day 4 after oestrus from superovulated adult ewes (Border Leicester $\times$ Scottish Blackface) that had been inseminated by a single sire (Dorset Horn) were synchronously transferred, singly, into the uteri of adolescent recipient ewes (Dorset Horn $\times$ Mule) as described by Wallace et al. (1997). All animals were housed in individual pens under natural lighting conditions at the Rowett Research Institute $\left(57^{\circ} \mathrm{N}, 2^{\circ} \mathrm{W}\right)$. The recipient ewes were approximately 7 months old and had a mean live weight of $45 \mathrm{~kg}$ at the start of the study. Immediately after embryo transfer, the adolescent ewes were allocated to one of two dietary treatments, so that the two groups were similar with respect to live weight, body condition score (Russel et al., 1969) and ovulation rate at the time of embryo transfer. Care was also taken to balance for donor embryo source where possible. Recipient ewes were offered individually, a high $(\mathrm{H}, n=42)$ or a moderate $(\mathrm{M}, n=32)$ amount of a complete diet (Wallace et al., 1996). The aim of these studies was to achieve rapid maternal growth rates throughout pregnancy in the group offered a high nutrient intake and to maintain a growth rate of $50-75 \mathrm{~g} \mathrm{day}^{-1}$ during the first 100 days of pregnancy in the group offered a moderate nutrient intake. The diet provided an estimated 10.2 MJ metabolizable energy $\mathrm{kg}^{-1}$ dry matter, $136.6 \mathrm{~g}$ crude protein $\mathrm{kg}^{-1}$ dry matter and had an average dry matter of $85.5 \%$. All ewes were offered their feed in two equal portions, at 08:00 h and 16:00 h each day. The daily feed refusal was weighed and recorded before the feed at 08:00 h. Moderate nutrient intake ewes were offered their experimental diets starting immediately after embryo transfer, whereas the amount of feed offered to high intake ewes was increased gradually over a 2 week period until the amount of daily feed refusal was approximately $15 \%$ of the total amount offered (equivalent to ad libitum intakes). Ewes were weighed each week and their body condition score was assessed at monthly intervals throughout gestation. The amount of feed offered was adjusted three times each week according to both live weight changes and feed refusals. After day 100 of gestation, the feed intake of the moderate nutrient intake ewes was increased each week to maintain body condition score during the final third of pregnancy and, hence, meet the estimated increasing demands of the developing fetus during late gestation.

At approximately day 50 of gestation, pregnancy was confirmed by transabdominal ultrasonography. Pregnancies were established and maintained in a total of 17 moderate and 30 high nutrient intake dams.

\section{Collection of tissue samples}

Ewes were killed at day $131 \pm 0.6$ of gestation. On this day, ewes received their morning feed, were weighed and body condition scores were recorded; the ewes were then killed by an i.v. administration of an overdose of sodium pentobarbitone (20 ml Euthesate; $200 \mathrm{mg}$ pentobarbitone $\mathrm{ml}^{-1}$; Willows Francis Veterinary, Crawley) and exsanguination was performed by severing the main vessels of the neck. The gravid uterus was removed immediately and opened. The fetus was killed by intracardiac administration of sodium pentobarbitone ( $5 \mathrm{ml}$ Euthesate). The umbilical cord was clamped and the fetus was removed, dried and weighed. The head was detached within 4 min of fetal death and the brain was collected and weighed. The pituitary gland was removed from the base of the brain and bisected in the coronal plane. Half of the anterior pituitary gland was placed in tissue-tek embedding medium and then snap-frozen in liquid nitrogen-chilled isopentane and stored at $-70^{\circ} \mathrm{C}$ until $\mathrm{LH} \beta$ and $\mathrm{FSH} \beta$ mRNA were quantified by in situ hybridization.

Fetal gonads were dissected, weighed and fixed immediately in Bouin's fixative for $6 \mathrm{~h}$ before being transferred to $70 \%(\mathrm{v} / \mathrm{v})$ ethanol. Gonadal tissue was then prepared for histology. The fetal liver was removed and weighed. All whole placentomes were dissected and the 
total masses were recorded. The singleton fetuses from six of 17 moderate nutrient intake dams and from 19 of 30 high nutrient intake dams were female and form the basis of this study.

\section{In situ hybridization}

In situ hybridization was performed on frozen sections using a technique similar to that of Sirinathsinghji et al. (1990). All chemicals were obtained from Sigma-Aldrich Co. (Poole) unless specified otherwise. Sense and antisense oligonucleotide probes (45 bases) were used (antisense; 5'CAGATGCTGGTGGTGAAAGTGATACAGACAGGGCAGGCCTCCTTC3', complementary to bases 124-168 of the ovine LH $\beta$ gene; D'Angelo-Bernard et al., 1990; EMBL accession no. X52488; and 5'GTGACATTCAGTGGCTACTGGGTACGTGTA CAGGGAGTCTGCATG3', complementary to bases 314-358 of the ovine FSH $\beta$ gene; Mountford et al., 1989; EMBL accession no. X15493; Oswel DNA service, Southampton). Probes were labelled with $\left[{ }^{35} \mathrm{~S}\right]$ deoxyadenosine 5'-(alpha-thio)triphosphate (dATP; $1300 \mathrm{Ci} \mathrm{mmol}^{-1}$; NEN, Life Science Products, Hounslow) using terminal deoxynucleotidyl transferase (TdT; Roche, Lewes) in a reaction mixture containing $1 \mu \mathrm{l}$ oligonucleotide (10 ng $\left.\mu^{-1}\right), 4 \mu \mathrm{l}$ diethyl pyrocarbonate (DEPC)-treated water, $2 \mu \mathrm{l}$ of $5 \times \mathrm{TdT}$ buffer, $1 \mu \mathrm{l} \mathrm{CoCl}_{2}, 1 \mu \mathrm{l}\left[{ }^{35} \mathrm{~S}\right] \mathrm{dATP}$ and $1 \mu \mathrm{l} \mathrm{TdT}$, and incubated at $37^{\circ} \mathrm{C}$ for $1 \mathrm{~h}$. The reaction was terminated by adding $40 \mu \mathrm{l}$ DEPC-treated water. After centrifugation through a Sephadex (G50) column at $1200 \mathrm{~g}$ for $10 \mathrm{~min}, 2 \mu \mathrm{l}\left(1 \mathrm{~mol}\right.$ dithiothreitol (DTT) $\mathrm{I}^{-1}$ ) was administered to prevent RNAase degradation. Sections from the same pituitary glands were probed with antisense and sense probes, simultaneously.

Coronal pituitary sections $(10 \mu \mathrm{m})$ from 11 growthrestricted and five normally developed fetuses (from high nutrient intake and moderate nutrient intake ewes, respectively) were cut on a cryostat and mounted onto poly-Llysine-coated slides. One pituitary gland from the moderate nutrient intake group was not included because it was damaged during dissection from the fetus. A decision was taken to compare the pituitary glands of growth-restricted fetuses from the high nutrient intake group with the normally grown fetuses from the moderate nutrient intake group because this number of slides (sense and antisense) could be processed in a single analysis. Slides were then fixed in $4 \%(\mathrm{w} / \mathrm{v})$ paraformaldehyde in DEPC-treated phosphate-PBS at $4^{\circ} \mathrm{C}$ for $5 \mathrm{~min}$, washed twice in PBS and dehydrated in a series of alcohol. Slides were removed from $95 \%$ alcohol and air-dried at room temperature. The labelled probe $(1 \mu \mathrm{l}$ at 150000 c.p.m. per slide) was mixed with $100 \mu$ l hybridization buffer per slide. The hybridization buffer contained 50\% (v/v) deionized formamide, $4 \times$ saline sodium citrate (SSC), 25 mmol sodium phosphate $\mathrm{I}^{-1}$, $\mathrm{pH} 7,1 \mathrm{mmol}$ sodium pyrophosphate $\mathrm{I}^{-1}, 0.5 \times$ Denhardt's $^{\prime}$ solution, $200 \mu \mathrm{g}$ salmon sperm DNA ml-1 (final), $100 \mu \mathrm{g}$ polyadenylic acid $\mathrm{ml}^{-1}$ (final), $120 \mu \mathrm{g}$ sodium heparin $\mathrm{ml}^{-1}$, $10 \%(\mathrm{w} / \mathrm{v})$ dextran sulphate and $20 \mathrm{mmol}^{\mathrm{DTT}} \mathrm{I}^{-1}$. Slides were hybridized overnight at $42^{\circ} \mathrm{C}$ with the radiolabelled oligonucleotide probe in hybridization buffer. After hybridization, slides were washed in $1 \times \mathrm{SSC}-0.5 \%(\mathrm{w} / \mathrm{v})$ $\beta$-mercaptoethanol at room temperature for $20 \mathrm{~min}$ on a rocking platform and in $1 \times \mathrm{SSC}-0.5 \%$ (w/v) $\beta$ mercaptoethanol at $55^{\circ} \mathrm{C}$ for $35 \mathrm{~min}$ in a shaking hybridization oven. The slides were then washed twice at room temperature in $1.0 \times \mathrm{SSC}$, and then once each in $0.1 \times$ SSC, $70 \%(\mathrm{v} / \mathrm{v})$ ethanol and $95 \%(\mathrm{v} / \mathrm{v})$ ethanol.

\section{Quantification of $m R N A$ expression}

Sections were air-dried and exposed to autoradiography film (Hyperfilm beta-max; Amersham International plc, Little Chalfont) at room temperature together with an autoradiographic $\left[{ }^{14} \mathrm{C}\right]$ micro-scale of $40-1070 \mathrm{nCi} \mathrm{g}$ (Amersham International plc). At the end of the 5 day exposure period, the autoradiograph film was developed and fixed using standard methods (Kodak developer/fixer GBX). This exposure time was selected as it allowed the weakest autoradiographic images to be quantified without the strongest images saturating the film. An image analysis system (Image Pro-Plus; Media Cybernetics, MD) was used to convert tissue equivalent radioactivity levels of scanned autoradiographic films (Umax Scanner; Astra 1220S, Dusseldorf) to absorbance of autoradiographs on the basis of the autoradiographic micro-scale. Average absorbance readings were taken from three sections per pituitary gland and mean absorbance values for each animal were then calculated.

Slides exposed previously to autoradiography film were coated with autoradiography silver emulsion (Hypercoat LM-1 emulsion; Amersham International plc). The emulsioncoated slides were stored in a light-tight box with silica gel at $4^{\circ} \mathrm{C}$ for 7 days. Slides were then developed and fixed with Kodak EDF/EDP photochemicals (Anachem, Luton) and counterstained with Mayer's haematoxylin solution. Slides were dehydrated in a series of ethanol and a coverslip mounted with DPX mountant (BDH Chemicals Ltd, Poole) to produce visible silver grains over the sites of hybridization. The number of silver grains produced was observed and photographed under dark-field illumination using an Olympus BH-2 microscope ( $\times 40$ objective) with Image Pro Plus software.

\section{Ovarian histology and morphometry}

The right ovary was dehydrated in a series of ethanol, cleared in xylene and embedded in paraffin wax. The ovary was then bisected transversely and both planar transections were embedded in the same paraffin wax block. Serial sections were cut at $5 \mu \mathrm{m}$ intervals and then stained with haematoxylin and eosin for examination of germ cell development. An average of 25 ovarian sections were examined per fetus. Stained ovarian sections were examined using a light microscope (Wang Biomedical, Microscopy Supplies and Consultants Ltd, Fife) with a $1 \mathrm{~cm}^{2}$ ocular graticule (21 mm; Agar Scientific, Stanstead) as follows. The 
Table 1. Gestational age at necropsy, placental mass and fetal weight, and fetal brain and liver mass in relation to maternal nutrient intake and growth status in late gestation sheep fetuses

\begin{tabular}{|c|c|c|c|c|c|c|}
\hline & \multicolumn{3}{|c|}{ Maternal nutrient intake } & \\
\hline & \multicolumn{3}{|c|}{ Fetal growth status } & \multicolumn{3}{|c|}{ Significance level } \\
\hline & Normal (M) & Restricted (H-R) & Normal $(\mathrm{H}-\mathrm{N})$ & $M$ versus $H-R$ & $\mathrm{M}$ versus $\mathrm{H}-\mathrm{N}$ & $\mathrm{H}-\mathrm{R}$ versus $\mathrm{H}-\mathrm{N}$ \\
\hline Number of pregnancies & 6 & 13 & 6 & & & \\
\hline Gestational age (days) & $132 \pm 1.7$ & $131 \pm 0.8$ & $131 \pm 1.3$ & ns & ns & ns \\
\hline Total placentome mass (g) & $442 \pm 54.3$ & $230 \pm 21.1$ & $354 \pm 24.5$ & $P<0.001$ & $\mathrm{~ns}$ & $P=0.01$ \\
\hline Fetal weight (g) & $4300 \pm 155.7$ & $2963 \pm 248.6$ & $4065 \pm 145.1$ & $P<0.001$ & $\mathrm{~ns}$ & $P<0.01$ \\
\hline $\begin{array}{l}\text { Adjusted fetal weight: day } \\
137 \text { of gestation (g) }\end{array}$ & $4599 \pm 104.6$ & $3213 \pm 269.8$ & $4428 \pm 130.3$ & $P<0.002$ & ns & $P<0.01$ \\
\hline Fetal brain mass (g) & $41.6 \pm 1.70$ & $36.4 \pm 1.35$ & $40.1 \pm 0.82$ & $P<0.02$ & ns & ns \\
\hline Fetal liver mass (g) & $127.5 \pm 7.12$ & $81.9 \pm 8.06$ & $123.4 \pm 8.52$ & $P<0.002$ & $\mathrm{~ns}$ & $P<0.01$ \\
\hline Fetal brain:liver mass & $0.33 \pm 0.018$ & $0.43 \pm 0.030$ & $0.33 \pm 0.020$ & $P<0.02$ & $\mathrm{~ns}$ & $P<0.02$ \\
\hline
\end{tabular}

Values are mean \pm SEM.

$\mathrm{M}$ : moderate; $\mathrm{H}-\mathrm{R}$ : high-restricted; $\mathrm{H}-\mathrm{N}$ : high-normal; ns: not significant.

width of the cortical tissue was measured at $\times 100$ magnification. Thereafter, four standard graticule areas were selected for each ovary and the number of germ cells was counted in a standardized manner between sections at a magnification of $\times 250$. Ovarian structures were classified as: oocytes (germ cells devoid of follicular cells and undergoing meiosis); primordial follicles (germ cells surrounded by flattened follicular cells); primary follicles (enlarged oocyte completely surrounded by one to two layers of cuboidal follicular cells); and secondary follicles (enlarged oocyte surrounded by two or more concentric layers of cuboidal cells), as described by Smith et al. (1994). The total number of follicles was estimated by first counting, and then averaging, the number of primordial, primary and secondary follicles for each graticule area in each cut section. Subsequently, an index of the total number of follicles was calculated by adding the results from the four graticule areas.

\section{Statistical analyses}

Fetal weight at necropsy was adjusted to a standard gestational age of 137 days (equivalent to the age of the oldest fetus studied) using the formula: adjusted fetal weight $=$ fetal weight at necropsy $(\mathrm{g}) \times 1.01305$ for each day of gestation. Fetuses from the high nutrient intake group were characterized as small or growth-restricted if fetal weight was $\leqslant$ the mean for moderate group fetuses minus two times the SD (Robinson et al., 1979). Thus, in this study, for this genotype a female fetus was considered to be growthrestricted if its adjusted weight was $<4086 \mathrm{~g}$. Consequently, 13 female fetuses derived from high nutrient intake dams were designated as growth-restricted and six as normalsized. Maternal live weight and body condition changes and gene expression data were analysed by Student's $t$ test. Pregnancy outcome and ovarian follicular data were examined by ANOVA, after which specific treatment comparisons were made by $t$ test using pooled SD. Correlation analysis was carried out by Pearson's product moment test where appropriate.

\section{Results}

\section{Maternal live weight and body condition}

At embryo transfer, the mean live weight and body condition scores for ewes that conceived and carried female fetuses were $47.1 \pm 0.88$ and $45.1 \pm 0.68 \mathrm{~kg}$, and $2.3 \pm 0.05$ and $2.2 \pm 0.03$ score units in the moderate and high nutrient intake groups, respectively. At approximately day 131 of gestation when the ewes were killed, mean live weights and body condition scores of ewes in the high and moderate nutrient groups were $73.4 \pm 1.87$ and $54.2 \pm 1.95 \mathrm{~kg}(P<0.001)$, and $3.3 \pm 0.06$ and $2.3 \pm 0.09$ score units $(P<0.001)$, respectively. The mean live weight gain during the first 100 days of gestation for the high and moderate nutrient intake groups was $306 \pm 19.6$ and $68 \pm 10.2$ g day $^{-1}$, respectively $(P<0.001)$.

\section{Placental and fetal growth}

Mean gestational age at necropsy and morphometric data relating to pregnancy outcome in high and moderate nutrient intake group pregnancies are shown (Table 1). High nutrient intake ewes were divided into those carrying normal-sized fetuses and those carrying growth-restricted fetuses as detailed above. Total placentome mass in the high nutrient intake dams with growth-restricted fetuses was 48 and $35 \%$ lower than that in the moderate $(P<0.001)$ and high nutrient intake groups $(P=0.01)$ with normalsized fetuses, respectively. Similarly, fetal liver masses were lower $(P<0.01)$ in the growth-restricted fetuses than in both groups of normal-sized fetuses (Table 1). Although fetal 
Table 2. $\mathrm{LH} \beta$ and FSH $\beta$ mRNA concentrations in the anterior pituitary gland of normally grown and growth-restricted late gestation female sheep fetuses

\begin{tabular}{|c|c|c|c|}
\hline \multicolumn{4}{|c|}{ Maternal nutrient intake } \\
\hline & Moderate & High & \multirow[b]{3}{*}{ Significance level } \\
\hline & \multicolumn{2}{|c|}{ Fetal growth status } & \\
\hline & Normal & Restricted & \\
\hline Number of fetuses & 5 & 11 & \\
\hline $\begin{array}{l}\mathrm{LH} \beta \text { mRNA }\left(\mathrm{nCi} \mathrm{g}^{-1}\right) \\
\text { (range) }\end{array}$ & $\begin{array}{c}172 \pm 23.6 \\
(118-238)\end{array}$ & $\begin{array}{c}252 \pm 21.6 \\
(136-345)\end{array}$ & $P<0.05$ \\
\hline $\begin{array}{l}\mathrm{FSH} \beta \mathrm{mRNA}\left(\mathrm{nCi} \mathrm{g}^{-1}\right) \\
\text { (range) }\end{array}$ & $\begin{array}{c}291 \pm 52.3 \\
(160-444)\end{array}$ & $\begin{array}{c}250 \pm 16.6 \\
(164-331)\end{array}$ & ns \\
\hline
\end{tabular}

Values are mean \pm SEM.

ns: not significant.

(A)

I

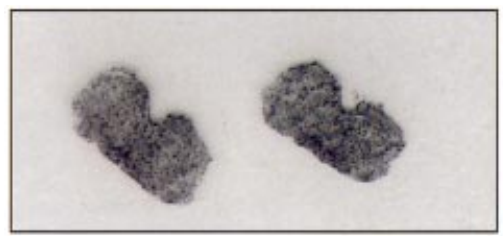

(b)

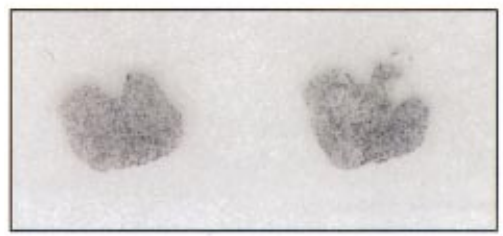

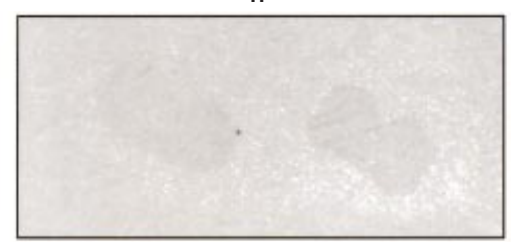

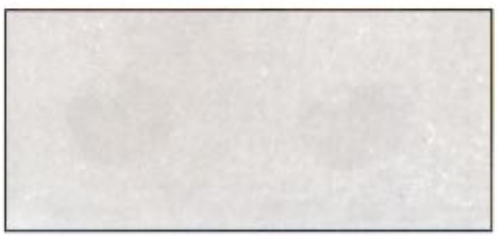

(B)
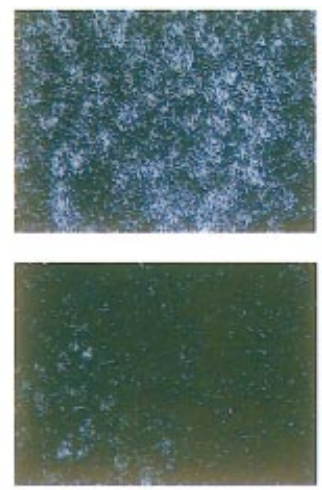

Fig. 1. (A) Film autoradiographs (I: antisense; II: sense) and (B) dark field photomicrographs ( $\times 400$ magnification) of fetal anterior pituitary gland sections hybridized to the LH $\beta$ probe in a representative (a) growthrestricted and (b) normally grown female sheep fetus.

brain mass was lower $(P<0.02)$ in the growth-restricted fetuses from high nutrient intake dams when compared with the normal-sized fetuses from the moderate nutrient intake group, the brain mass to liver mass ratio was higher in growth-restricted fetuses when compared with both groups of normal-sized fetuses $(P<0.02)$. Irrespective of nutritional treatment, fetal weight at autopsy was positively correlated with total placental mass $(r=0.793, n=25, P<0.001)$. A similar relationship was observed between total placentome mass and the mass of the fetal brain $(r=0.712, n=25$, $P<0.001)$ and liver $(r=0.883, n=25, P<0.001)$.

\section{Fetal pituitary $L H \beta$ and $F S H \beta$ gene expression}

The amount of LH $\beta$ mRNA in the fetal pituitary gland was significantly higher $(P<0.05)$ in growth-restricted fetuses from high nutrient intake dams compared with normally grown female fetuses from moderate nutrient intake dams (Table 2). Irrespective of growth status, LH mRNA expression was negatively correlated with total placentome mass $(r=-0.535, n=16, P<0.05)$. Film autoradiographs and dark-field photomicrographs of representative fetal pituitary sections hybridized to the LH $\beta$ probe are illustrated (Fig. 1). There was no significant effect of maternal nutritional treatment on fetal pituitary FSH $\beta$ mRNA expression (Table 2).

\section{Ovarian development}

The ovarian sections of the two most severely growthrestricted fetuses were difficult to cut and were of poor quality after staining. Although these ovaries were virtually devoid of follicles of any type, the data were not included in the overall group mean, as insufficient high quality sections for accurate quantification were obtained. The weights of these two fetuses were 1217 and $1460 \mathrm{~g}$, respectively.

Neither ovarian mass nor the width of the cortical layer was influenced by maternal nutritional treatment or fetal growth status (Table 3 ). In contrast, the total number of ovarian follicles (per four graticule areas) was lower in both growth-restricted $(P<0.002)$ and normal-sized fetuses 
Table 3. Ovarian mass and number of germ cells in relation to maternal nutrient intake and growth status in sheep fetuses

\begin{tabular}{|c|c|c|c|c|c|c|}
\hline & \multicolumn{3}{|c|}{ Maternal nutrient intake } & \multirow{3}{*}{\multicolumn{3}{|c|}{ Significance level }} \\
\hline & Moderate & High & High & & & \\
\hline & \multicolumn{3}{|c|}{ Fetal growth status } & & & \\
\hline & Normal (M) & Restricted (H-R) & Normal $(\mathrm{H}-\mathrm{N})$ & $M$ versus $H-R$ & $\mathrm{M}$ versus $\mathrm{H}-\mathrm{N}$ & $\mathrm{H}-\mathrm{R}$ versus $\mathrm{H}-\mathrm{N}$ \\
\hline Number of fetuses & 6 & 11 & 6 & & & \\
\hline Ovarian mass (mg) & $87 \pm 15.3$ & $75 \pm 9.3$ & $94 \pm 24.0$ & ns & ns & $\mathrm{ns}$ \\
\hline Cortical layer width (mm) & $0.34 \pm 0.018$ & $0.33 \pm 0.020$ & $0.32 \pm 0.037$ & ns & ns & ns \\
\hline $\begin{array}{l}\text { Total number of follicles per } \\
\text { four graticule areas (range) }\end{array}$ & $\begin{array}{c}91.0 \pm 23.37 \\
(40-191)\end{array}$ & $\begin{array}{l}29.2 \pm 5.27 \\
\quad(11-62)\end{array}$ & $\begin{array}{l}45.0 \pm 10.20 \\
\quad(18-83)\end{array}$ & $P<0.002$ & $P<0.01$ & ns \\
\hline Number of primordial follicles & $66.8 \pm 22.71$ & $12.1 \pm 4.88$ & $24.3 \pm 6.22$ & $P<0.002$ & ns & ns \\
\hline Number of primary follicles & $22.1 \pm 8.42$ & $16.1 \pm 4.63$ & $19.9 \pm 8.97$ & ns & ns & ns \\
\hline Number of secondary follicles & $2.2 \pm 1.01$ & $1.0 \pm 0.41$ & $0.82 \pm 0.508$ & ns & ns & ns \\
\hline
\end{tabular}

Values are mean \pm SEM.

M: moderate; H-R: high-restricted; $\mathrm{H}-\mathrm{N}$ : high-normal; ns: not significant.
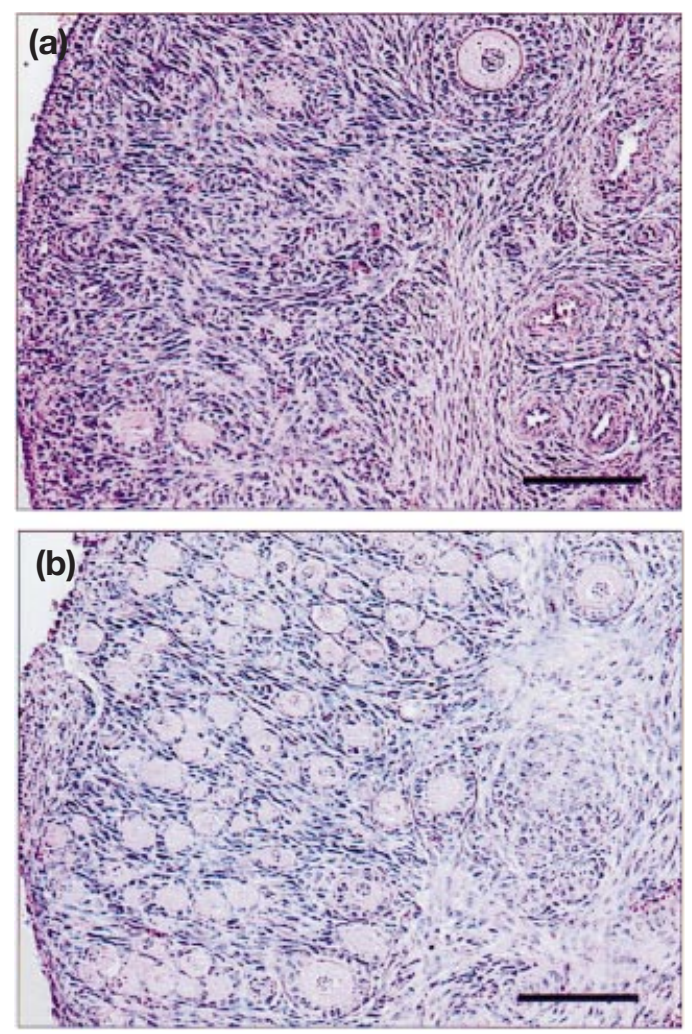

Fig. 2. Photomicrographs illustrating the number and distribution of follicles in the ovarian cortex of a representative (a) growthrestricted and (b) normally developed female sheep fetus. Scale bars represent $100 \mu \mathrm{m}$.

$(P<0.01)$ from high nutrient intake dams compared with normally grown fetuses from moderate intake dams (Fig. 2, Table 3). Within the high nutrient intake group, total follicle number was independent of growth status.

The effect on the overall number of follicles was primarily attributable to differences in the number of primordial

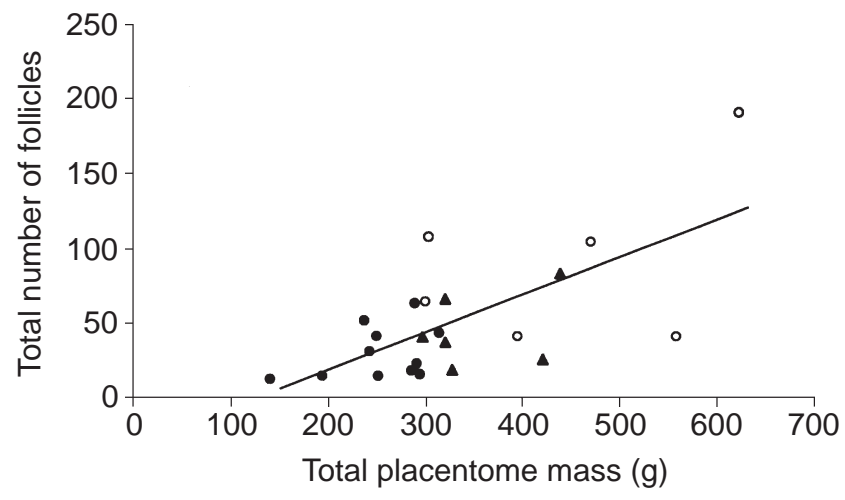

Fig. 3. Relationship between total placentome mass and total number of ovarian follicles in growth-restricted $(\bullet)$ and normalsized sheep fetuses from the high $(\mathbf{\Delta})$ and moderate $(\bigcirc)$ dietary intake groups, respectively $(y=0.242 x-30.46)$.

follicles, the numbers of which were significantly lower $(P<0.002)$ in growth-restricted compared with normalsized fetuses from the moderate nutrient intake group. Irrespective of maternal nutritional treatment, the total number of follicles was positively correlated with fetal weight $(r=0.552, n=23, P<0.01)$. There was a similar relationship between both primordial and total number of follicles and total placentome mass $(r=0.719, n=23$, $P<0.01$ and $r=0.654, n=23, P<0.01$, respectively, Fig. 3).

\section{Discussion}

In the present study, overnourishing adolescent dams throughout pregnancy resulted in rapid maternal growth rates at the expense of the nutrient requirements of the gravid uterus as reported by Wallace et al. (1996, 2000). Consequently, two-thirds of the resulting fetuses from the high nutrient intake dams were categorized as growthrestricted, whereas the placental mass and fetal weight of 
the remaining fetuses were not significantly different from the moderate intake or control group. However, irrespective of fetal growth status within the overnourished group, high maternal dietary intakes throughout pregnancy were associated with a reduction in the total number of ovarian follicles present at day 131 of gestation compared with the moderate dietary intake group. This effect was largely attributable to a reduction in the number of primordial follicles. Indeed, the number of primordial follicles expressed as a ratio to ovary mass in fetuses derived from high nutrient intake dams was approximately four-fold less than that observed in normally grown fetuses from moderate nutrient intake ewes. This finding may reflect a decrease in either mitotic or meiotic activity of the germ cells and, thus, fewer oocytes entering the process of follicular formation and/or an increase in cell atresia during the period of early follicular growth (McNatty et al., 1995). The concept of maternal nutrition influencing the rate of cell atresia is supported by the study of Borwick et al. (1997) in which fetal germ cell degeneration was delayed when adult ewes were undernourished from mating until tissue collection at either day 47 or day 62 of gestation. Although at first glance the results of these two studies appear to be contradictory, the fetuses in both studies were almost certainly subject to reduced nutrient availability compared with the corresponding control fetuses, albeit via different mechanisms. Thus, in the undernourished adult model, the concentrations of nutrients in the maternal circulation would be anticipated to be low and hence fewer nutrients would be available for uptake by the placenta. In contrast, in the overnourished adolescent model, the availability of nutrients in the maternal circulation is high but the growthrestricted placenta limits both the uptake and transport of essential nutrients to the fetus (Wallace et al., 2001). In either case, impaired ovarian development may be the result of inadequate nutrient availability at the fetus, which may subsequently modify the fetal insulin and insulin-like growth factor I (IGF-I) system and hence may compromise normal ovarian organogenesis. Indeed, insulin and IGF-I comprise a family of mitogenic peptides and the genes encoding their receptors are present in human fetal ovaries from early in gestation (Shifren et al., 1993). Furthermore, Wallace et al. (2000) reported that glucose, insulin and IGF-I concentrations are significantly attenuated in growthrestricted fetuses from overnourished dams during late gestation.

Although mean placental mass was not significantly lower in the high nutrient intake dams carrying normalsized fetuses when compared with the moderate nutrient intake dams, the strong positive correlation between placental mass and the number of ovarian follicles irrespective of maternal nutritional status implies that impaired placental growth or function may be central to the reduction in the number of follicles observed during late gestation. As this is the first study in sheep to examine the influence of placental growth restriction on number of ovarian follicles there are no comparable data. However, de Bruin et al. (1998) reported a similar depletion of follicles in the ovaries of growth-restricted human fetuses derived as a result of placental insufficiency and hence perinatal death between week 25 and week 33 of gestation.

During fetal life the placenta is a major source of a range of growth factors and hormones, and it is possible that these may directly (via endocrine or paracrine mechanisms) or indirectly (via alterations in blood flow and local nutrient supply) influence fetal ovarian development. For example, several angiogenic growth factors and their receptors have been identified in the ovine placenta and, putatively, may be involved in the differentiation of various organ systems in addition to playing a role in the growth and vascular development of the placenta per se (Cheung et al., 1995; Dore et al., 1995; Zheng et al., 1997). Wallace et al. (1997, 2000) demonstrated that the maternal concentrations of a range of placental hormones are attenuated in overnourished dams particularly during the second half of gestation, but have not yet determined whether placental growth factor expression is similarly affected. It is possible that these growth factors and/or hormones of placental origin may interact with ovarian-derived growth factors and their receptors. Intraovarian steroids are crucial for the developmental organization and/or maturation of both the somatic and germ cells (Lun et al., 1998; McNatty et al., 2000). In addition, a range of peptide growth factors and their receptors have been identified in ovine (McNatty et al., 1999, 2000) and human (Bennett et al., 1996; Schilling and Yeh, 1999) fetal ovaries before follicular formation, indicating an autocrine or paracrine role in the regulation of ovarian development. Although these studies are in their infancy, the adolescent model used in the present study may provide a useful tool to elucidate the role of these various candidate growth factors and hormones in fetal ovarian development.

The reduction in the number of follicles in the normalsized fetuses from the high nutrient intake dams is intriguing in view of the fact that the masses of the fetal brain, ovaries and liver and body weights per se were identical to those of fetuses from moderate nutrient intake ewes. This finding reinforces the concept that nutritional manipulation of the dam can programme alterations in organ system development independently of changes in fetal weight or in organ mass (Harding and Johnston, 1995; Hawkins et al., 2000); these effects can persist until adulthood (Itoh et al., 1999). Similarly, as the number of ovarian follicles available for recruitment at puberty and thereafter is set during fetal life, it is possible that the depletion in the ovarian follicle population observed in fetuses derived from high nutrient intake dams could influence reproductive performance in adult life. Clearly this hypothesis requires to be tested.

In the present study, fetal growth restriction was associated with enhanced expression of LH $\mathrm{mRNA}$ in the pituitary gland. Two potential mechanisms could explain this observation. Firstly, the fetal pituitary gland of growth-restricted lambs may be responding to altered feedback from the fetal ovaries and placenta. The extent to which oestrogens and 
inhibin from the developing ovaries can regulate pituitary function during late gestation is unknown. Functional oestrogen receptors are present in the pituitary gland of normally growing fetuses after day 105 of gestation (Gluckman et al., 1983) and the abundance of LH-secreting cells in the fetal pituitary gland is increased after ovariectomy of female fetuses at day 115 of gestation (Hadj Messaoud-Toumi et al., 1993). Thus, it is possible that the follicle-depleted ovaries of the growth-restricted fetuses in the present study could be associated with an attenuated negative feedback signal on the fetal pituitary gland. However, the placenta is the primary source of fetal oestrogens (Findlay and Cox, 1970; Findlay and Seamark, 1973), which have a profound effect on fetal gonadotrophin secretion during late gestation (Miller and Brooks, 1999). As the amount of fetal pituitary LH $\beta$ mRNA measured in the present study was negatively correlated with total placentome mass, it is suggested that the small placenta of the growth-restricted fetuses produced a smaller oestrogen feedback signal on the fetal pituitary resulting in enhanced LH $\beta$ expression.

Alternatively, the enhanced expression of LH $\beta$ mRNA may be attributable to a temporal delay in the maturation of the pituitary gland of the slow-growing fetuses during late gestation. Immunocytochemistry revealed a small but significant reduction in the number of fetal pituitary cells expressing $\mathrm{LH} \beta$ between day 100 and day 130 of gestation in normally growing fetuses (Sheng et al., 1998). Clearly, if the maturational reduction in the number of $\mathrm{LH}$ gonadotrophs within the pituitary gland is delayed in growth-restricted fetuses, this could account for the higher LH $\beta$ mRNA expression detected. In support of this hypothesis, very high gonadotrophin concentrations have been reported in prematurely born female infants $(80 \%$ gestation; Tapanainen et al., 1981). However, it was not possible to find an effect of fetal growth restriction on pituitary FSH $\beta$ mRNA expression, presumably because ovarian steroids are not involved in the regulation of fetal pituitary FSH secretion. Indeed, Mesiano et al. (1991) reported no effect of ovariectomy on plasma FSH concentrations in female fetuses at days 100-115 of gestation. It is also unlikely that ovarian inhibin contributes to the regulation of fetal pituitary $\mathrm{FSH}$ secretion as expression of $\alpha$ inhibin mRNA is detected only after days 130-140 of gestation when it is localized in secondary and antral follicles (Engelhardt et al., 1995). As there were no differences in the number of secondary follicles between growth-restricted and normally grown fetuses, it is unlikely that ovarian inhibin exerted a regulatory role in pituitary $\mathrm{FSH}$ gene expression in female fetuses in the present study.

In conclusion, the use of the pregnant adolescent sheep model has shown that high maternal nutrient intakes during pregnancy have a negative effect on fetal ovarian development as assessed during late gestation. This effect was evident in both growth-restricted and normal-sized fetuses derived from high nutrient intake dams. It remains to be established whether this altered prenatal follicular develop- ment resulted from restriction of placental growth per se or from nutritionally mediated changes in the intra-ovarian milieu.

The authors thank A. N. Brooks for the gift of the oligonucleotide probes for ovine pituitary $\mathrm{LH} \beta$ and $\mathrm{FSH} \beta$ mRNA and for providing training with respect to in situ procedures to P. Da Silva. The statistical advice of G. Horgan (BIOSS) is gratefully acknowledged. This work was supported by the Scottish Executive Environment and Rural Affairs Department and Praxis XXI.

\section{References}

Bennett A, Osathanondh R and Yeh J (1996) Immunohistochemical localization of transforming growth factor- $\alpha$, epidermal growth factor (EGF) and EGF receptor in the human foetal ovary Journal of Clinical Endocrinology and Metabolism 81 3073-3076

Borwick SC, Rhind SM, McMillen SR and Racey PA (1997) Effect of undernutrition of ewes from the time of mating on foetal ovarian development in mid-gestation Reproduction, Fertility and Development $9711-715$

Brooks AN, Currie IS, Gibson F and Thomas GB (1992) Neuroendocrine regulation of sheep fetuses Journal of Reproduction and Fertility Supplement 45 69-84

Brooks AN, McNeilly AS and Thomas GB (1995) Role of GnRH in the ontogeny and regulation of the fetal hypothalamo-pituitary-gonadal axis in sheep Journal of Reproduction and Fertility Supplement 49 163-175

Caldani M, Antoine M, Batailler M and Duittoz A (1995) Ontogeny of GnRH systems Journal of Reproduction and Fertility Supplement 49 147-162

Cheung CY, Singh M, Ebaugh MJ and Brace RA (1995) Vascular endothelial growth factor gene expression in ovine placenta and fetal membranes American Journal of Obstetrics and Gynecology 173 753-759

Cresswell JL, Barker DJP, Osmond C, Egger P, Phillips DIW and Fraser RB (1997) Fetal growth, length and polycystic ovaries in adult life The Lancet 350 1131-1135

D'Angelo-Bernard G, Moumni M, Jutisz M and Counis R (1990) Cloning and sequence analysis of the cDNA for the precursor of the beta subunit of ovine luteinizing hormone Nucleic Acids Research 18 2175-2182

Da Silva P, Aitken RP, Rhind SM, Racey PA and Wallace JM (2001) Influence of placentally-mediated foetal growth restriction on the onset of puberty in male and female lambs Reproduction 122 375-383

de Bruin JP, Dorland M, Bruinse HW, Spliet W, Nikkels PGJ and Te Velde ER (1998) Fetal growth retardation as a cause of impaired ovarian development Early Human Development 51 39-46

Dore JJ, Jr, Wilkinson JE and Godkin JD (1995) Early gestational expression on transforming growth factor beta isoforms by the ovine placenta Biology of Reproduction 53 143-152

Engelhardt H, Harkness LM, Thomas GB, Brooks AN, McNeilly AS and Baird DT (1995) Expression of inhibin alpha- and beta A-subunit mRNA and protein in the fetal sheep ovary throughout gestation Molecular and Cellular Endocrinology 107 141-147

Findlay JK and Cox RI (1970) Oestrogens in the plasma of the sheep foetus Journal of Endocrinology 46 281-282

Findlay JK and Seamark RF (1973) The occurrence and metabolism of oestrogens in the sheep foetus and placenta. In The Endocrinology of Pregnancy and Parturition pp 54 Ed. C Pierrepoint. Alpha Omega Alpha, Cardiff

Francois I, de Zegher F, Spiessens C, D'Hooghe T and Vanderschuren D (1997) Low birth weight and subsequent male subfertility Pediatric Research 42 899-901

Gluckman PD, Marti-Henneberg C, Kaplan SL and Crumbach MM (1983) Hormone ontogeny in the ovine fetus. XIV. The effect of $17 \beta$-estradiol infusion on fetal plasma gonadotrophins and prolactin and the maturation of sex steroid-dependent negative feedback Endocrinology $1121618-1623$ 
Hadj Messaoud-Toumi L, Taragnat C and Durand P (1993) Castration effects on the gonadotrope populations of the fetal sheep pituitary in late gestation Neuroendocrinology 58 548-554

Harding JE and Johnston BM (1995) Nutrition and fetal growth Reproduction, Fertility and Development 7 539-547

Hawkins P, Steyn C, Ozaki T, Saito T, Noakes DE and Hanson MA (2000) Effect of maternal undernutrition in early gestation on ovine fetal blood pressure and cardiovascular reflexes American Journal of Physiology. Regulatory, Integrative and Comparative Physiology 279 R340-R348

Ibãnez L, Ferrer A, Marcos MV, Hierro FR and de Zegher F (2000a) Early puberty: rapid progression and reduced final height in girls with low birth weight Pediatrics 106 E72

Ibãnez L, Potau N, Enriquez G and de Zegher F (2000b) Reduced uterine and ovarian size in adolescent girls born small for gestational age Pediatric Research 47 575-577

Itoh S, Steyn C, Green LR, Noakes D and Hanson MA (1999) Long-term effects on the lamb of mild undernutrition during early gestation Journal of Physiology, London $\mathbf{5 2 8} 36$

Lun S, Smith P, Lundy T, O'Connell A, Hudson N and McNatty KP (1998) Steroid contents of and steroidogenesis in vitro by the developing gonad and mesonephros around sexual differentiation in fetal sheep Journal of Reproduction and Fertility 114 131-139

McNatty KP, Smith P, Hudson NL, Heath DA, Tisdall DJ, O WS and Braw-Tal R (1995) Development of the sheep ovary during fetal and early neonatal life and the effect of fecundity genes Journal of Reproduction and Fertility Supplement 49 123-135

McNatty KP, Heath DA, Lundy T, Fidler AE, Quirke L, $\mathrm{O}^{\prime}$ Connell A, Smith P, Groome N and Tisdall DJ (1999) Control of early ovarian follicular development Journal of Reproduction and Fertility Supplement 54 3-16

McNatty KP, Fidler AE, Juengel JL, Quirke LD, Smith PR, Heath DA, Lundy T, O'Connell A and Tisdall DJ (2000) Growth and paracrine factors regulating follicular formation and cellular function Molecular and Cellular Endocrinology 163 11-20

Mesiano S, Hart CS, Heyer BW, Kaplan SL and Grumbach MM (1991) Hormone ontogeny in the ovine fetus. XXVI. A sex difference in the effect of castration on the hypothalamic-pituitary gonadotrophin unit in the ovine fetus Endocrinology 129 3073-3079

Miller DW and Brooks AN (1999) Placental steroids are involved in the late-gestation decrease in gonadotrophin secretion in the ovine fetus Proceedings of the British Society of Animal Science Abstract 66

Mountford PS, Bello PA, Brandon MR and Adams TE (1989) Cloning and DNA-sequence analysis of the CDNA for the precursor of ovine folliclestimulating hormone beta-subunit Nucleic Acids Research 17 6391-6396

Mueller PL, Sklar CA, Gluckman PD, Kaplan SL and Grumbach MM (1981) Hormone ontogeny in the ovine fetus. IX. Luteinizing hormone and follicle-stimulating hormone response to luteinizing hormone-releasing factor in mid- and late gestation and in the neonate Endocrinology 108 881-886

Robinson JJ (1977) The influence of maternal nutrition on ovine foetal growth Proceedings of the Nutrition Society 36 9-16

Robinson JJ, Sinclair KD and McEvoy TG (1999) Nutritional effects on foetal growth Animal Science 68 315-331

Robinson JS, Kingston EJ, Jones CT and Thorburn GD (1979) Studies on experimental growth retardation in sheep. The effect of removal of endometrial caruncles on fetal size and metabolism Journal of Developmental Physiology 1 379-398

Russel AJF, Doney JM and Gunn RG (1969) Subjective assessment of body fat in live sheep Journal of Agricultural Science Cambridge 72 451-454

Schilling B and Yeh J (1999) Expression of transforming growth factor (TGF)$\beta 1$, TGF- $\beta 2$ and TGF- $\beta 3$ and of type I and II TGF- $\beta$ receptors during the development of the human fetal ovary Fertility and Sterility 72 147-153

Sheng C, McNeilly AS and Brooks AN (1998) Immunohistochemical distribution of oestrogen receptor and luteinizing hormone $\beta$ subunit in the ovine pituitary gland during foetal development Journal of Neuroendocrinology 10 713-718

Shifren JL, Osathanondh R and Yeh J (1993) Human fetal ovaries and uteri: developmental expression of genes encoding the insulin, insulin-like growth factor I and insulin-like growth factor II receptors Fertility and Sterility 59 1036-1040

Sirinathsinghii DJS, Morris BJ, Widen W, Northrop A, Hunt SP and Dunnett SB (1990) Gene expression in striatial grafts - I. Cellular localization of neurotransmitter mRNAs Neuroscience 34 675-686

Smith P, Braw-Tal R, Corrigan K, Hudson NL, Heath DA and McNatty KP (1994) Ontogeny of ovarian follicle development in Booroola sheep fetuses that are homozygous carriers or non-carriers of the $\mathrm{Fec}^{\mathrm{B}}$ gene Journal of Reproduction and Fertility 100 485-490

Tapanainen J, Koivisto M, Vihko R and Huhtaniemi I (1981) Enhanced activity of the pituitary-gonadal axis in premature human infants Journal of Clinical Endocrinology and Metabolism 52 235-238

Thomas GB, McNeilly AS and Brooks AN (1993) Development of gonadotrophs and thyrotrophs in the female foetal sheep pituitary: immunocytochemical localization studies Journal of Neuroendocrinology 5 157-161

Wallace JM, Aitken RP and Cheyne MA (1996) Nutrient partitioning and fetal growth in rapidly growing adolescent ewes Journal of Reproduction and Fertility 107 183-190

Wallace JM, Da Silva P, Aitken RP and Cheyne MA (1997) Maternal endocrine status in relation to pregnancy outcome in rapidly growing adolescent sheep Journal of Endocrinology 155 359-368

Wallace JM, Bourke DA, Aitken RP, Palmer RM, Da Silva P and Cruickshank MA (2000) Relationship between nutritionally-mediated placental growth restriction and fetal growth, body composition and endocrine status during late gestation in adolescent sheep Placenta $\mathbf{2 1}$ 100-108

Wallace JM, Bourke DA, Aitken RP, Milne JS, Leitch N and Hay WW, Jr (2001) Uterine and umbilical blood flows and glucose uptakes in growth-restricted pregnancies induced by overnourishing adolescent sheep Reproduction Abstract Series $\mathbf{2 7} 53$

Zheng J, Vagnoni KE, Bird IM and Magness RR (1997) Expression of basic fibroblast growth factor, endothelial mitogenic activity and angiotensin II type-I receptors in the ovine placenta during the third trimester of pregnancy Biology of Reproduction 56 1189-1197

Received 2 November 2001.

First decision 25 January 2002.

Accepted 13 February 2002. 